\title{
Statement by Corinne Cicéron Bühler
}

\author{
Director of the Directorate for International Law and Legal Advisor \\ of the Swiss Federal Department of Foreign Affairs
}

(Translation from the French original)

I am honoured to participate today in this solemn meeting, as a representative of the host State of the meetings of the International Law Commission. I have the pleasure to address to you a few words, on behalf of the Federal Council, to mark the seventieth anniversary of the International Law Commission, commemorated under the ambitious theme "Drawing a balance for the future".

Since the end of the Cold War, the world has been in a constant state of flux. The balance of power at the international level is shifting in a context marked by globalization and fragmentation. International relations have become more important, but also more complex, particularly against the backdrop of the prevailing volatile environment. Has international law had its day? No, quite the opposite. This is why it is crucial to recognize and emphasize its fundamental role in inter-State relations.

The progressive development and codification of international law are essential for the maintenance of a stable, just and peaceful international order, especially in a world faced with upheavals. International law constitutes the guarantee that international relations will be based not on the law of force but, on the contrary, on the force of law.

As a small, highly interconnected State, Switzerland is particularly interested in the maintenance and strengthening of international law. This strengthening is not only a fundamental tenet of the Charter of the United Nations, but is also essential for Swiss foreign policy. This observation was true 70 years ago, and it remains fully relevant today.

No single country or actor on the world stage is capable of finding the solutions to today's challenges alone. The same holds true for legal issues; hence the importance of the work of the International Law Commission.

While the Commission continues to address topics of general international law, such as the law of treaties and the immunity of State officials, it also has been dealing with more contemporary issues, such as the protection of the atmosphere, the protection of the environment in relation to armed conflict and the protection of persons in the event of disasters. Indeed, the International Law Commission is mandated to focus on the progressive development of new rules aimed at addressing the problems of today's world. This focus 
will increase the relevance and effectiveness of international law. After all, the Commission was established to encourage the progressive development of international law, not only its codification.

The value of the International Law Commission's work has been well established; its draft articles are considered authoritative legal texts and often are interpreted as statements of law by domestic courts.

It is therefore a great honour for Switzerland to host the Commission's meetings in Geneva, thereby contributing to its crucial work. I wish to recall the remarks made by my colleague, Ambassador Jürg Lauber, on 21 May at the solemn meeting in New York: the choice of Geneva as the seat of the Commission's meetings guarantees that it carries out its work with complete independence vis-à-vis the Sixth Committee, which is based in New York, and whose work Switzerland also highly appreciates. The diversity of legal cultures specific to these two bodies is an asset for the development of international law. A presence in Geneva ensures synergies with the many international organizations, platforms and international actors which are based in Geneva and which influence everyone's daily lives.

Furthermore, Switzerland considers it very important that international law is promoted not only from New York, but also from the European Headquarters of the United Nations, in Geneva. In this context, I wish to highlight the International Law Seminar, held annually in Geneva, which enables its participants - officials, faculty and students - to follow the work of the International Law Commission from up close. One of my duties, as the Legal Advisor of the Federal Department of Foreign Affairs, is specifically to monitor the development and codification of international law. I am therefore particularly pleased that the Commission carries out a substantial portion of its work in Switzerland.

On behalf of the Swiss Government, I wish to assure you that Switzerland, the host State of the Commission, will continue to support the Commission's work and to do whatever is necessary for its members to conduct their work successfully in the most conducive setting.

As I mentioned earlier, it is a great honour for me to be among you today to commemorate this important anniversary. I have no doubt that today's discussions on the theme "Drawing a balance for the future" will bear fruit, and I am already looking forward to hearing the outcomes of your deliberations. It remains for me to wish you all the best for the work ahead of you, and to thank you for your attention. 